\title{
Fetal-Maternal Hemorrhage
}

National Cancer Institute

\section{Source}

National Cancer Institute. Fetal-Maternal Hemorrhage. NCI Thesaurus. Code C113149.

Loss of fetal blood into the maternal circulation. 